\title{
Banking Union Perspectives of Eurozone Peripheries: A Critical View
}

\author{
Dimitrios G Tsoutsas* \\ Department of Economics, University of Thessaly, Greece
}

Submission: April 04, 2018; Published: September 10, 2018

"Corresponding author: Dimitrios G Tsoutsas, Department of Economics, University of Thessaly, Greece, Email: dts@hotmail.gr

\begin{abstract}
This paper studies the perspectives of the Eurozone becoming a banking union apart from a monetary one. Risk- and debt-sharing of the financial sector between Eurozone member peripheries are under scrutiny and moral hazard incentives from the side of banking institutions are analyzed. While looking into advantages and drawbacks of debt mutualization, the beneficial character of a strongly-linked banking union is discussed, but also the rigorous constraints it has to overcome.
\end{abstract}

JEL Classification: G15, F41, F45.

Keywords: Eurozone peripheries; Debt mutualization and Banking union

Abbreviations: EMU: European Monetary Union; ECB: European Central Bank; LTROs: Long-Term Refinancing Operations; CBBPs: Covered Bond Purchase Programs; LOFR: Lender of First Resort; LOLR: Lender of Last Resort; ESM: European Stability Mechanism; NPLs: Non-Performing Loans; OMT: Outright Monetary Transactions Program; ERP: European Redemption Pact; FDIC: Federal Deposit Insurance Cooperation

\section{Introduction}

When evaluating the efficacy of the European Monetary Union (EMU), one should separate this period under examination into two sub-periods. The first one is the period before the onset of the recent financial crisis that was triggered by the Lehman Brothers collapse in 2008. The second, and perhaps more interesting one, is the period after 2008, when the first signs of the US leverage-fed domino effects showed up in the EU, as it is highly affected by shocks in the US, due to its overexposure to the latter and its weakly diversified banking system [1]. Starting in 2009, the European Central Bank (ECB) realized unconventional monetary actions but not in an intense level. A series of Long-Term Refinancing Operations (LTROs) were employed, and two series of Covered Bond Purchase Programs (CBBPs) in 2009 and 2011 [2]. There has been a voluminous literature on unconventional monetary practices in major economies such as the US, the UK, Japan, and the Eurozone due to necessity for confronting liquidity shortages since 2008 [3] Martin and[4-8].The Lehman Brothers default having triggered a leverage-spurred domino effect in bank-centric economies such as the Eurozone has led many economists arguing on whether further money injections are necessary, or it is time for QE-exit [9]. Interestingly, supporters of monetary easing argue that further balance sheet enlargement in the ECB is necessary for leading the money-hungry Eurozone financial system not to run out of fuel in a time period where debt accumulation lowers economic activity in Greece, Spain, Portugal, and Italy. On the other hand, those who prefer financial stability refuse further money issuance and looser bank lending conditions as this reduces the Euro's purchasing power. The aim of this paper is not to support either of the two views, but rather to highlight the advantages and drawbacks of each alternative and contribute towards a better understanding of the current dilemma. One of the main aspects of monetary and fiscal policy nowadays that needs a thorough analysis is whether the ECB could sacrifice part of its credibility by allowing to be affected by political pressures exercised by indebted Eurozone economies in order to "ease" money-printing standards. In other words, is the highly prestigious credibility-evoked independency of monetary authorities more valuable that the benefit from the flexibility that further money printing brings about in times of crisis?

Even though the liquidity-supplying QE measures since 2008 have been effective in the US, the UK, and Japan, the embryonic level of unconventional monetary policies in the Eurozone does not permit to form an accurate opinion regarding their efficacy based on past experience. Nevertheless, a lot of interest has aroused about whether Eurozone banks could even survive if liquidity drainage due to crisis-led risk aversion kept up with no more money infusions available. Supporters of stability claim that the ECB should not by any means become a Lender of First Resort (LOFR), rather than the taking up the role of Lender of Last Resort (LOLR) it usually keeps. One of the basic questions in direct need of answering is which is the critical level of substituting credibility with flexibility, and by how 
much this should be faced as extraordinary times that require extraordinary measures. Should we really support the economy revival at any cost?

The remainder of this paper is structured as follows: Section 2 provides description and evaluation of Eurozone characteristics. Section 3 is about the perspectives of a banking union are under scrutiny. In Section 4, the feasibility of forming a banking union among Eurozone peripheries is discussed. The questions of whether debt mutualization is appropriate and how well could a Eurozone banking union perform in comparison with the US, are answered in Section 5. Finally, Section 6 concludes.

\section{Evaluating the Eurozone Characteristics}

Architects of the Euro believed that the Eurozone would become a more flexible union of economies than national economies themselves, and that would help European countries converge regarding their economic sectors. Moreover, they intended to form a flexible and stress-enduring union that would protect its members from highly unanticipated shocks, such as financial crises. Thereby, national debt levels could lower, and the monetary union could open the way for the creation of a fiscal and banking union as well. Furthermore, all members having the same currency could mitigate high volatility and large exchange fluctuations, so would bring about financial and economic stability and a safer ground for investments. For a banking union to be successful, common supervising and resolution should be feasible in order to prevent fiscal costs from growing [10]. In the Treaty of European Union, European governments commit themselves to take necessary actions for their economies to converge, that is to be flexible enough to work together in order to have economic stability and efficacy. By having Eurozone securing its members from non-anticipated external shocks, each member would not have to conduct "easing" policies in case of an adverse shock, meaning that it would not have to increase its public debt in order to spur the national economy. Raising public debt is usually the most effective tool an individual country has to prevent its economy from indulging into recession. On the other hand, this creation of inflationary pressures and a higher burden for next generations, as well as perturbing normality in the business cycle, are primary problems that the European Monetary Union (EMU) commitment for stability could resolve. In other words, a monetary union brings equilibrium in markets much more easily than national governance.

One of the prerequisites for each country wishing to enter the EMU was to have low debt in order to prevent the appearance of high instability-provoking national deficits. Nevertheless, a high portion of countries entered the union having high debt-to-GDP ratios (57\% for France, $60 \%$ for Germany, 103\% for Greece, and $108 \%$ for Italy), which for some kept growing even some years after having joined the EMU. That is, $64 \%, 68 \%, 106 \%$, and $106 \%$, for France, Germany, Greece, and Italy, respectively, in 2006. The latter indicated that the Stability Growth Pact which was set up in 2008, proved ineffective as national budgets could not render in surpluses or even balanced. Whereas convergence to fiscal stability was far from being achieved, financial integration between European national markets proved to be easier, largely helped by the bank-centric character of European countries, as well as the Eurozone as a whole. Money markets quickly integrated, and lending to investors and households became much cheaper due to easy accessibility to a much larger supply of funds. The latter was helped by the European-membership creditworthiness. The same was true for equity markets, helped by the Financial Services Action Plan, which meant an attempt for a single market for financial services that was created in 1999 in order to last until 2005. Although the intention when creating the Eurozone was to evoke stability, and financial markets' cheap money supplying integration was favorable to this purpose, results deviated much from the targets. High prosperity in money markets brought about a very high level of leverage between financial institutions in the Eurozone and a boom in credit supply. Thereby, inflationary pressures emerged and most importantly a high-risk appetite was created among European investors due to the "cheap money" offered by the EU banking system. In other words, money was not used for safe and growth-fulfilling investments as intended by policymakers, but rather to highly profitable but at the same time too risky investments.

Particularly, Eurozone countries with less wealth were better opportunities for fast and large profits, so they faced higher investment and less saving. The latter though was not a problem as the credit-hungry financial system was increasingly fed by the credit-nourishing developed European banking system. "Liquidity kills quickly, solvency does not", claim the supporters of modern monetary thinking and mean that if a country or an institution runs out of liquidity, then it is almost certain that it will default. High levels of liquidity being feasible through high leverage, means that only fiat money created by banks in the form of promises can increase the level of money circulating in an economy. There is nothing wrong, they claim, with printing fiat money as long as an external shock such as a financial crisis does not come and shake the fragile base of this enormous self-perpetuating creation. Such an external shock is exactly what happened when the too highly leveraged (36 times more than its equity!) Lehman Brothers was not bailed-out by the US government and triggered the financial crisis.

\section{Perspectives of a Banking Union}

As Goodhart [11] argues, if banking supervision is applied in a European level, resolution and recapitalization should also be shared between Eurozone members, so the role of the ECB would become strengthened. A banking union would contribute to make the connection between countries and their national banks less tight in order for risk contagion from one to the other to lessen. This would reduce risks that governments such as the Spanish, the Irish, and the Icelandic have suffered concerning their fiscal sanity because their national risk-hungry, lobby-tied 
and politically directed banks would not affect them so much. In order for the ECB to be capable of effectively confronting such risks, moral hazard-fed bailout needs should be diminished, and financial institutions in danger should be successfully immunized from the rest of the banking system and closed down. The European monetary authorities represented by the ECB should therefore render capable of minimizing the costs of banking resolution in case of default as well as to make this procedure externality-proof. No matter if the Eurozone peripheries could be described as a new form of a federal union in the strict sense or not, bank supervision but also bank resolution should be incorporated into the main responsibilities of the Eurozone's monetary planner.

The main question that has raised a lot of intriguing conflict nowadays between academics, market practitioners and generally economic units, is whether the increasing tax-serviced cost of saving the indebted banks could be pushed away from taxpayers so that they could be substantially alleviated. In other words, is it possible to shift the bank sector debt-financing burden to banks themselves or their creditors without risk of provoking a new fierce crisis episode? Is bailing-in of financial institutions more viable than bailing-out from taxpayers? One of the most prominent views regarding this dilemma is that it all has to do with the timing of the actions engendered. If the measures adopted are contractionary as concerns the credithungry Eurozone banking system, that is if bail-in strategies were imposed by the ECB, then a deep new crisis could probably emerge. The most-known example is of course that of the Lehman Brothers collapse-evoked domino effects in an effort for large financial institutions' moral hazard incentives to be attenuated. On the other hand, if bailing-out by higher taxes and more inflation boom-triggering money printing continues, a new giant price bubble and immense lowering of real values would seem inevitable, bringing a brand-new crisis when the bubble blasts. Moreover, monetary policy measures like the well-known "Draghi's bazooka" for liquidity injecting that carry side effects, should be best used and not wasted only for bank recapitalization if it has no value-added in terms of efficiency. Furthermore, should the European Stability Mechanism (ESM) help in bank recapitalization of highly indebted countries such as Spain charge their tax burden only to national taxpayers or should it be shared to all Eurozone countries tax-paying citizens? While financially healthy countries such as Germany are reluctant to pay for others debt, more modest opinions argue that the indebted country's government should be held responsible for half of the burden, whereas the other half could be paid by all Eurozone members in tandem with the ECB's provisions. That could render to be an efficient way of reducing inequalities between Eurozone peripheries and attenuate conflict of interestaroused disputes between them. Another interesting proposal is that bank losses which are mainly driven by non-performing loans (NPLs) should be prevented and that debt burden could preferably be shared among Eurozone members before financial institutions' default. Monetary economy functioning through the bank lending channel has aroused significant academic work regarding how banks should manage their assets, and which are the best asset management strategies for having higher bank profits $[12,13]$. Nevertheless, sharing the debt burden brings about issues concerning how fair it would be for a high risktaking banks country to load a large part of its risky assets to a safe-asset oriented banks country. Therefore, the rule that no solution comes without controversy counts here too.

Looking from a different point of view, rational monetary policy practicing should also have deep knowledge of the chaineffects that bail-in strategies could lead to for an economy. Higher costs for banks in order to service their debt, and firesales regarding their assets, would probably lead to higher intermediation margins thereby more expensive access to funds for investors. This could provoke irrevocable damage in the highly bank-centric structure of the Eurozone financial system, and costs of reaching again a market-efficient equilibrium could become prohibitive in the medium- or long-run. Moreover, if trying to act in a preventive manner, the ECB could try to impose penalties on banking institutions to prevent them from excessive risk-sharing or make them pay a higher portion of the financial burden in their country as their risk-loving is to blame. This is where the problem of difficulties in defining risk comes to the forefront.

A somewhat different scenario would be to make uncensored senior bondholders of a financial institution instead of taxpayers pay for its damages. Such bondholders usually are hedge funds, which most times manage to escape from "paying the bill", as in the case of Ireland where terms on issue were not suitable for applying bailing-in regulation. Imposing penalties on wealthy individuals or hedge funds could be a solution for lowering the burden on taxpayers and redistribute losses in a fairer manner. Nevertheless, in the majority of times, pension funds and insurance schemes also hold significant fractions of bank bonds, thereby risk for penalty imposing would also be transferred to them. Consequently, by this indirect manner, tax-paying individuals would again suffer a large part of the bank losses, which would be larger than in the bail-out scenario. Generally, bailing-out the financial system's indebtedness is considered as a cheap way of debt servicing in comparison to bailing-in, thereby offering higher flexibility to authorities for handling crises. Once more, flexibility has to coincide with the right momentum in action-taking in order not to become anticipated, thereby ineffective.

\section{Feasibility of a Banking Union Between Eurozone Pe- ripheries}

In order to institutionally restructure Europe, the formation of a banking union is a long-term plan whose primary precursor is the construction of a single supervisory mechanism. The main aim of such a mechanism would be to supervise, to restructure, and to provide insurance for deposits. It is found that complementarities between responsibilities of supervision and 
exercising monetary policy are very important for the efficiency of monetary policymaking [14]. In order for this formation to be effective, three aspects should be emphasized. First, it should rely on strict restrictions on fiscal policy as well as provision for the case that sovereign countries default. Second, financial regulation and supervision should be common and to count for every member of the Eurozone. Third, insolvent countries should be helped by a European crisis mechanism. Special attention should be paid on sovereign debt problems, as they are highly related to credit problems in Eurozone's financial institutions and also have a negative effect on the real economy by lowering GDP and employment. In order for this mechanism to reach a level where liability and control would have long-term viability, national sovereignty should be restricted, in order for cohesion in implementing the necessary reforms to be achieved. It could be clearly said that stability and durability over a banking union agreement relies heavily on fiscal consolidation and lower amounts of debt. In an effort for recovery of the highly indebted Eurozone countries, economies should grow in tandem with interest rates being prevented from becoming too high. The latter though gets hard to realize as sovereign risk in countries such as Greece, Italy, and Spain, that is the weaker Eurozone peripheries, gets higher thereby increasing the Eurozone's systemic risk.

According to Tornell and Westermann [15] without the essential reforms, indebted Eurozone countries will very often be in the need of expansionary monetary policies. Contagion effects due to common policy demand easing measures by the ECB in the form of Quantitative Easing, Credit Easing or the Enhanced Credit Support, at the detriment of economically strong countries $[2,5]$. This results in a further conflict of interests between financially healthy and distressed countries and the continuation of "beggar-thy-neighbor" effects, as ample liquidity provisions and sovereign debt monetization divide Eurozone members into opposing parties. Particularly, the ECB has injected money in banks with favorable terms and has allowed for more eligible assets suitable for refinancing operations. Moreover, it has introduced the Outright Monetary Transactions Program (OMT) in tight connection to the ESM mechanism.

Despite efforts about preventing from too lax policies in the common monetary framework by adjusting bond issuance by indebted countries, the existence of secondary sovereign bonds markets that permit high fluctuations on bonds' prices and thereby yields, allow monetizing sovereign debts in a large extent. In rendering the stability in fiscal policies as a prerequisite and a feedback factor for achieving monetary stability, as well as for forming a stable banking union, proposals had to be made in order to succeed in fiscal stabilization. The European Redemption Pact (ERP) was proposed in 2011 with the aim to provide the necessary stabilization perspectives of a viable long-term character. The main motive of setting up this proposal was for preventing moral hazard incentives arousing between countries, as they could try to hide fiscal balance problems for a long time until their problem becomes so large that Lender of Last Resort aid by the ECB became necessary. The main orientation of the ERP is to impose breaks on national debt. Therefore, if a country would not abide by these breaks, then penalties should be imposed and paid to the ERP [16]. Interestingly, ERP was considered for being implemented not on highly indebted countries already in the European Stability Mechanism (ESM) adjustment program such as Greece, Ireland, Portugal, or Cyprus until recently. In case of large deviations of countries under the ERP from directions of the latter, even exclusion from participating in this mechanism could take place. Furthermore, in order for moral hazard incentives to be limited, collateral has to be pledged by each country equal to one fifth of the debt it has outsourced to this mechanism, so this country would comply by the rules in order not to lose such an amount and need to impose new taxes. Thereby, this could make a good motivation for politicians to obey the rules because differently they would not manage to be reelected. Therefore, attachment of sovereign policy to preserving the Euro will be high, in order for the Eurozone's monetary authorities to be more effective. If this could become feasible, then indebted countries could be allowed to reformulate their structures in order to become more crisisproof in hard times.

An interesting aspect that has not received as much attention up to present as it is worth, is whether the ECB would render less or more risk-averse in the case its authorities were enlarged and had to direct a banking union in the Eurozone, not only a monetary one. One aspect supports that if the ECB was also the head of a Eurozone banking union, bank supervision could improve by far due to lack of fear to face troubled financial institutions efficiently. Namely, the independency of monetary authorities could lead to bank recapitalization in a much earlier stage, meaning that large losses and tax burdens could be ruled out. On the other hand, it is believed that because of the ECB being responsible for preventing systemic banking crises, it would be more prone to succumb to needs for often refinancing and this would lead to moral hazard incentives of banks and higher needs for taxation or further inflationary pressures. In other words, while national central banks are not responsible for the conduct of monetary policy, in contrast to the ECB, they could prove more effective in imposing restrictions to financial institutions of a country. Moreover, the much larger budget of the ECB in tandem with its printing flexibility, which is more intense with fears of crisis, could make the risk-oriented banking institutions more agile and willing to take on risks. This increase in moral hazard incentives would inevitably worsen the ECB's trading strategy and increase fears for moral suasion in risksharing among Eurozone members. Thus, more bail-outs would be expected to emerge.

If one takes into consideration the interconnectedness between national financial sectors within the Eurozone, bank runs, and the liquidity drainage makes the Eurozone banking sector more dependent on economies of scale and leverage dynamics, thereby increasing hesitation about taking 
precautionary measures. For once more, it could be confirmed that imposing losses on creditors could prove much more costly than imposing taxes. Moreover, deposit insurance and resolution could be realized only with adequate funding from taxes. Furthermore, if a national economy's banking sector collapsed, then the costs of reviving this economy would be much higher than higher taxes. It should not be neglected though that if the ECB could manage to form and preserve its credibility by not increasing inflation too much through money printing and easing monetary policy, the recovery from a crisis would be much easier if a banking union framework was applied. This is easily explained by lower interbank barriers in cross-border lending.

\section{Could the Eurozone Banking Union become Successful as in the US?}

The intriguing question of whether a Eurozone banking union could become firm enough so as not to be swept off when confronting shocks, could find an answer based on formerly set up monetary and banking unions. The most prominent example is that of the US, where the Federal Deposit Insurance Cooperation (FDIC) was created in 1933-34 in an effort to help the country recover and construct a firewall for banking crises after the Great Recession. The efficacy of the FDIC for more than eighty years has been based on its ability to alter the level of insurance risk premia and supervision [17]. Interestingly, it is capable of withstanding the payment for bank losses and effective in supervising and providing liquidity, but not without control by the federal government. In the Eurozone, where fiscal governance is more of a special case, it is seen that a fiscal union could serve well as a sine qua non for stability in a monetary and banking union. This way, lines of credit from the ECB could be drawn to national governments as a whole and the credibility of such a system would give much greater flexibility to the Eurozone's monetary authorities for acting. Moreover, debt financing by monetization would render much cheaper and easy interbank money lending would provide help to national governments in order to have viable national debts and not default. Overall, debt mutualization could exist but be limited in order to prevent moral dishonesty. The transparency in the combination of monetary, financial, and fiscal authorities would keep yields in low levels due to credibility, thereby would boost investment.

Moreover, a unified banking sector would be powerful enough to lay restrictions on large banking institutions by imposing a high lending price in terms of high risk premiums to banks that misbehave. This way, prevention would become more efficient. Setting up a partial debt mutualization mechanism could prevent large wreckages in the Eurozone construction and also be beneficial for non-immoral banking. In order for this to be stable, every component of it should be well tied to another. New constructions rely on the structure of their parts in order to resist adverse conditions. This is why many believe that tying the Eurozone countries by three pillars of cohesion would render it much more flexible but also resistant to external perils. As
Goodhart and Schoenmakerb [18] argue, recapitalizing banks is efficient only if the social benefits in terms of stability are higher than the social cost. Suitable institutional modifications within the Eurozone peripheries should lead to faster common decisionmaking and to long-lasting transparency-generated stability. National constraints should be relaxed by suitable regulations by national authorities, despite the paradox of regulation [19] in order for maximizing the total outcome that could result in higher values. But the latter is far from an easy task!

\section{Conclusion}

This paper analyzes the character of the European Union's banking system and looks into whether the Eurozone could become a banking and perhaps fiscal union, apart from a monetary one. It is argued that imbalances among Eurozone peripheries and differences in regulation should be effectively managed in order for this to be feasible. This way, the ECB could render capable of exercising authorities not only as a monetary planner, but also for common bank supervising and resolution. This means that the Eurozone could be secured from external shocks and the need for extraordinary unconventional monetary measures could be reduced, resulting in lower inflationary pressures. It is argued here that fiscal policy cohesion is a prerequisite for monetary stability and feasibility of forming a banking union.

An important matter under scrutiny in this study is whether the ECB directing bank regulations could lead to worse or better outcomes concerning moral hazard incentives for excessive risktaking and thereby higher needs for bail-outs. By taking into consideration the credit-oriented character of the Eurozone's banking system, it is very possible that a banking union could bring about larger domino effects in case it was affected by external shocks. Interestingly enough, the credibility through transparency of the common monetary and banking authorities in case of a banking union, could lead to higher benefits than losses. Namely, if structural reforms for all Eurozone members in national level were successful, the ECB could render resistant but also flexible enough to effectively confront negative external nuisance. Nevertheless, the prerequisite being a fiscal union leaves much space for doubt regarding the practicability of a common banking structure for Eurozone peripheries.

\section{References}

1. Schoenmaker D, Wagner W (2013) Cross-Border Banking in Europe and Financial Stability. International Finance 16(1): 1-22.

2. Szczerbowicz U (2015) The ECB unconventional monetary policies: have they lowered market borrowing costs for banks and governments? International Journal of Central Banking 11(4): 91-127.

3. Fawley BW, Neely CJ (2013) Four stories of quantitative easing. Federal Reserve Bank of St. Louis Review 95(1): 51-88.

4. Martin C, Milas C (2012) Quantitative easing: a Sceptical survey. Oxford Review of Economic Policy 28(4): 750-764.

5. d'Amico S, English W, López-Salido D, Nelson E (2012) The Federal Reserve's Large-scale Asset Purchase Programmes: Rationale and Effects. The Economic Journal 122(564): 415-F446. 
6. Wright JH (2012) What does monetary policy do to long-term interest rates at the zero-lower bound? The Economic Journal 122(564): F447-F466.

7. Falagiarda M (2014) Evaluating quantitative easing: a DSGE approach. International Journal of Monetary Economics and Finance 7(4): 302 327.

8. Hanisch M (2017) The effectiveness of conventional and unconventional monetary policy: Evidence from a structural dynamic factor model for Japan. Journal of International Money and Finance 70: 110-134.

9. Blinder AS (2010) Quantitative Easing: Entrance and Exit Strategies. Federal Reserve Bank of St. Louis Review 92(6): 465-479.

10. Pisani-Ferry J, Wolff G (2012) The fiscal implications of a banking union, Bruegel.

11. Goodhart C (2012) Funding arrangements and burden sharing in banking resolution. Banking Union for Europe, Europe , pp. 105.

12. Kashyap AK, Stein JC, Wilcox DW (1993) Monetary policy and credit conditions: Evidence from the composition of external finance. The American Economic Review 83(1): 78-98.
13. Oliner SD, Rudebusch GD (1996) Monetary policy and credit conditions: evidence from the composition of external finance: comment. The American Economic Review 86(1): 300-309.

14. Peek J, Rosengren ES, Tootell GM (1999) Is bank supervision central to central banking? The Quarterly Journal of Economics 114(2): 629-653.

15. Tornell A, Westermann F (2012) The tragedy of the commons at the European Central Bank and the next rescue. Vox EU, pp. 22.

16. Buch CM, Weigert B (2012) Legacy problems in transition to a banking union. Banking Union for Europe, Europe, pp. 25.

17. Aizenman J (2012) US Banking over two centuries: Lessons for the Eurozone crisis. Banking Union for Europe, 129.

18. Goodhart C, Schoenmakerb D (2009) Fiscal Burden Sharing in CrossBorder Banking Crises. International Journal of Central Banking.

19. Aizenman J (2012) The Euro and the global crises: finding the balance between short term stabilization and forward-looking reforms .National Bureau of Economic Research, Inc, USA.

\section{Your next submission with Juniper Publishers will reach you the below assets}

- Quality Editorial service

- Swift Peer Review

- Reprints availability

- E-prints Service

- Manuscript Podcast for convenient understanding

- Global attainment for your research

- Manuscript accessibility in different formats

( Pdf, E-pub, Full Text, Audio)

- Unceasing customer service

Track the below URL for one-step submission https://juniperpublishers.com/online-submission.php 